Konstanzer Online-Publikations-System (KOPS)

URL: http://www.ub.uni-konstanz.de/kops/volltexte/2008/6936/

URN: http://nbn-resolving.de/urn:nbn:de:bsz:352-opus-69366

\title{
$s$-Triazines as Nitrogen Sources for Bacteria
}

\author{
Alasdair M. Cook* and Ralf Hütter
}

Isolation of bacteria able to utilize $s$-triazines as the sole and limiting nitrogen sources for growth is described. Three strains of Pseudomonas (A, D, and F) and two strains of Klebsiella pneumoniae (90 and 99 ) were examined. Strains $D$ and $F$ utilized $N$-ethylammelide, $N$-isopropylammelide, ammeline, ammelide, cyanuric acid, and ammonium ion as nitrogen sources. Strain A utilized melamine, ammeline, ammelide, cyanuric acid, ammonium ion, and deaminated $N$-ethylammeline and $N$-isopropylammeline. Strains 90 and 99 utilized ammelide, cyanuric acid, and ammonium ion. Growth yields of strains were independent of the nitrogen source, and specific growth rates with $s$-triazines were similar to those with ammonium ion as the nitrogen source $\left(\sim 0.3-0.6 \mathrm{~h}^{-1}\right)$. Suspensions of nongrowing cells generally gave quantitative yields of ammonium ion from $s$-triazines, and ring carbon atoms were released as carbon dioxide. $N$-Alkylammelines in mixtures of strains $\mathrm{A}$ and $\mathrm{D}$ were quantitatively degraded to ammonium ion.

Papers claiming microbial degradation of $s$-triazines, usually herbicides, are widespread, but reviewers have various interpretations of the rates of $s$-triazine degradation. Thus Alexander (1979) labels $s$-triazines recalcitrant, Cripps and Roberts (1978) imply ready degradability, whereas other reviewers refrain from comment (Esser et al., 1975; Kaufman and Kearney, 1970; Knuesli et al., 1969;

Mikrobiologisches Institut, Eidgenössische Technische Hochschule, ETH-Zentrum, CH-8092 Zürich, Switzerland.
Harris et al., 1968). Jordan et al. (1970) complement these data by citing extensive nonbiological degradation of $s$ triazines, usually on clay mineral surfaces. $s$-Triazines do not accumulate in the soils studied by Ramsteiner et al. (1972).

Metabolites from $s$-triazines in experiments with animals, plants, and microorganisms have been reviewed by Fishbein (1975). Definitive proof of $s$-triazine metabolism by microorganisms in pure culture has been provided (Kaufman and Blake, 1970; Kaufman et al., 1965, 1963; Kearney et al., 1965). Simazine (6-chloro- $N, N^{\prime}$-diethyl- 
Table I. s-Triazines

\begin{tabular}{|c|c|c|}
\hline abbreviation & chemical name & common name \\
\hline & $\begin{array}{l}\text { 6-chloro- } N \text {-ethyl- } N^{\prime}-(1 \text {-methylethyl)-1,3,5-triazine-2,4-diamine } \\
N \text {-ethyl- } N^{\prime}-(1 \text {-methylethyl)-6-(methylthio)-1,3,5-triazine-2,4-diamine } \\
N, N^{\prime} \text {-bis }(1 \text {-methylethyl)-6-(methylthio)-1,3,5-triazine-2,4-diamine } \\
4,6 \text {-bis(ethylamino }-1,3,5 \text {-triazine-2(1H)-one } \\
4 \text {-(ethylamino)-6-[(1-methylethyl)amino }]-1,3,5 \text {-triazine- } 2(1 H) \text {-one } \\
4,6 \text {-bis }[(1 \text {-methylethyl)amino }]-1,3,5 \text {-triazine-2(1H)-one }\end{array}$ & $\begin{array}{l}\text { atrazine } \\
\text { ametryne } \\
\text { prometryne } \\
\text { hydroxysimazine } \\
\text { hydroxyatrazine } \\
\text { hydroxyprometryne }\end{array}$ \\
\hline CEAT & 6-chloro- $N$-ethyl-1,3,5-triazine-2,4-diamine & deethylsimazine \\
\hline CIAT & 6-chloro- $N$-(1-methylethyl $)-1,3,5$-triazine-2,4-diamine & deethylatrazine \\
\hline NEN & 4-amino-6-(ethylamino)-1,3,5-triazine-2(1H)-one & $N$-ethylammeline \\
\hline NIN & 4-amino-6-[(1-methylethyl)amino $]-1,3,5$-triazine- $2(1 H)$-one & $N$-isopropylammeline \\
\hline NED & 6-(ethylamino $)-1,3,5$-triazine- $2,4(1 H, 3 H)$-dione & $N$-ethylammelide \\
\hline NID & $6-[(1$-methylethyl $)$ amino $]-1,3,5$-triazine-2,4(1H,3H)-dione & $N$-isopropylammelide \\
\hline $\mathrm{MN}$ & $1,3,5$-triazine-2,4,6-triamine & melamine \\
\hline $\mathrm{AN}$ & 4,6-diamino-1,3,5-triazine-2(1H)-one & ammeline \\
\hline $\mathrm{AD}$ & 6-amino-1,3,5-triazine-2,4(1H,3H)-dione & ammelide \\
\hline $\mathrm{CN}$ & $1,3,5$-triazine- $2,4,6(1 H, 3 H, 5 H)$-trione & cyanuric acid \\
\hline
\end{tabular}
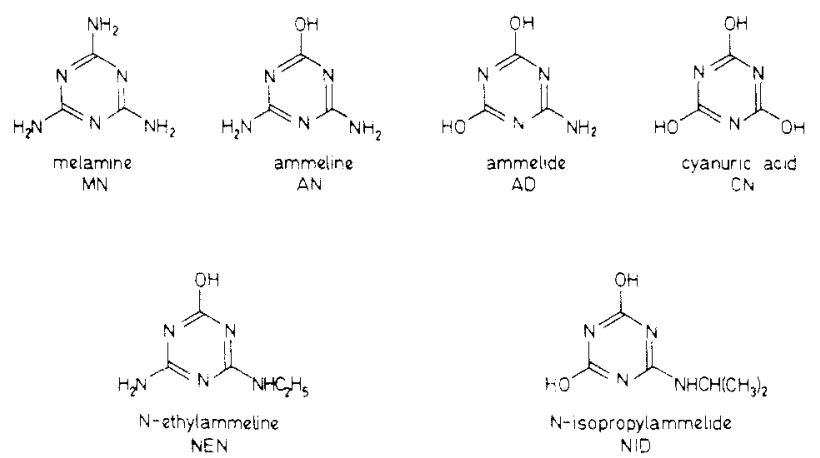

Figure 1. Structures, names, and abbreviations of some $s$-triazines degraded in this study.

1,3,5-triazine-2,4-diamine, $25 \mu \mathrm{M})$ was dealkylated over 7 days to 6-chloro- $N$-ethyl-1,3,5-triazine-2,4-diamine ( $\sim 16$ $\mu \mathrm{M})$ and an unidentified second product. A simple, presumably naturally occurring $s$-triazine, cyanuric acid (Wise and Walters, 1917), has been reported as a nitrogen source for fungi (Zeyer, 1979; Wolf and Martin, 1975; Jensen and Abdel-Ghaffar, 1969) and anaerobic sewage (Saldick, 1974), but only Zeyer (1979) finds rapid degradation $(\sim 0.1$ mkat/g of protein). None of these organisms would seem applicable to the degradation of the many $s$-triazines in the wastes from herbicide manufacture.

We now present definitive evidence for rapid and complete bacterial degradation to ammonium ion (or cell material) of the $s$-triazines cyanuric acid, ammelide, ammeline, melamine, and four $N$-alkylated ammelides and ammelines. The ring carbon was released as carbon dioxide. A portion of these data was discussed in a review (Cook and Hütter, 1981).

\section{EXPERIMENTAL SECTION}

Materials. The $s$-triazines used (Table I, including abbreviations; see also Figure 1) were of high purity, as described in the preceding paper (Beilstein et al., 1981). Ring-U-14 $\mathrm{C}$-labeled $s$-triazines $(9-106 \mathrm{GBq} / \mathrm{mol})$ were provided by Ciba-Geigy (Basel, Switzerland) and were used without further purification. Radiochemical purity was determined by thin-layer chromatography as described by Zeyer (1979) with the following results: NIN (91\%) contained AN (8\%) and three unidentified impurities $(1 \%)$; NEN $(80 \%)$ was contaminated by AN $(20 \%)$; NID $(98 \%)$ contained small amounts of NIN $(0.5 \%)$ and CN $(0.5 \%)$ and an unknown contaminant ( $1 \%)$; no impurities were detected in AN and CN. All other chemicals were of reagent grade or better.

Apparatus, Analysis, and Identification of Metabolites. Spectrophotometric analyses were done using a
Beckman Acta CIII or a Bausch \& Lomb Spectronic 88 spectrophotometer, each equipped with a flow-through cell of $1.0-\mathrm{cm}$ path length. Turbidity was measured in a Bausch \& Lomb Spectronic 20 colorimeter with round cells of $12-\mathrm{mm}$ path length. High-pressure liquid chromatography (HPLC) was done as described in the preceding paper (Beilstein et al., 1981). The identity of an organic compound, tentatively assigned by cochromatography with HPLC, was confirmed by obtaining mass spectra by direct insertion in a Hitachi Perkin-Elmer RMU $6 \mathrm{M}$ mass spectrometer using electron impact ionization at $70 \mathrm{eV}$. Radioactivity was measured in a Beckman LS 7000 liquid scintillation analyzer. Electron microscopy was done with a Philips EM 301 electron microscope. Samples were prepared in a Balzers BAF 30 freeze etcher.

$s$-Triazines were routinely measured and tentatively identified by HPLC as described in the preceding paper (Beilstein et al., 1981). Ammonium ion was routinely determined and tentatively identified by the method of Weatherburn (1967). The identification of ammonium ion was confirmed by reaction with glutamate dehydrogenase (EC 1.4.1.3) (da Fonseca-Wollheim et al., 1974) and by use of an ammonia electrode (Type 95-10; Orion Research, Cambridge, MA) coupled to an ionalyzer (701 A, Orion) in the low-level measurement mode as described in the manufacturer's instructions.

Radiorespirometry was done as described by Conrad and Schlegel (1977). The cell density in the reaction mixtures was about $0.3 \mathrm{mg}$ of protein $/ \mathrm{mL}$; the initial concentration of $s$-triazine was about $0.5 \mathrm{mM}$ and contained about 200 $\mathrm{Bq}$ of ${ }^{14} \mathrm{C}$. Reactions $(1 \mathrm{~mL})$ were stopped after overnight incubation. The radioactivity measured was not converted to absolute units because of the difficulty of calibrating radioactivity in the filter paper after trapping with $\mathrm{KOH}$.

Growth was measured routinely as protein (rather than turbidity or dry weight) to eliminate trivial complications arising from the accumulation of lipid or carbohydrate storage polymers. Bacteria were precipitated with $0.5 \mathrm{M}$ trichloroacetic acid (final concentration) and collected by centrifugation $\left(20000 \mathrm{~g}\right.$ for $20 \mathrm{~min}$ at $4^{\circ} \mathrm{C}$ ) after which the supernatant fluid was discarded and the walls of the centrifuge tube were dried with a cotton swab. The bacteria were suspended in $0.66 \mathrm{M} \mathrm{NaOH}$ and assayed for protein (Kennedy and Fewson, 1968). In calculations from published data, protein in microorganisms was considered to be $0.5 \times$ dry weight (Lehninger, 1975). Substrate utilization rates were calculated in katals (kat; $\mathrm{mol} / \mathrm{s}$ ) [e.g., Lehninger (1975)].

Growth Media and the Isolation of Organisms. The growth medium used for nitrogen-limited growth was in $10 \mathrm{mM}$ potassium phosphate buffer, $\mathrm{pH} 7.3$, and contained 
$0.25 \mathrm{mM} \mathrm{MgSO}_{4}$, carbon source(s) (see below), a nitrogen source ( $\leq 2.5 \mathrm{mM}$ nitrogen), and trace elements. The buffered solution of $\mathrm{MgSO}_{4}$ was autoclaved, and sterile solutions of trace elements, carbon source(s), and nitrogen source were added aseptically and then adjusted aseptically to $\mathrm{pH} 7.3 \pm 0.2$ if necessary [i.e., when the triazine was dissolved in acid (or base), an equal volume of sterile, equimolar base (or acid) was added]. Trace elements (Pfennig and Lippert, 1966; this solution was supplemented with $100 \mathrm{mg} \mathrm{CaCl}{ }_{2} \cdot 2 \mathrm{H}_{2} \mathrm{O} / \mathrm{L}$ and was supplied at $5 \mathrm{~mL} / \mathrm{L}$ ) were sterilized by autoclaving. Carbon sources or $s$-triazines in solution were sterilized by passage through filter membranes of $0.2-\mu \mathrm{m}$ pore diameter and of the appropriate chemical resistance (SM 113, SM 118, or SM 119; Sartorius, Göttingen, FRG). The following stock solutions of $s$-triazines were used: $30 \mathrm{mM}$ hydroxysimazine, $30 \mathrm{mM}$ hydroxyatrazine, $30 \mathrm{mM}$ hydroxyprometryne, $10 \mathrm{mM}$ NEN, $10 \mathrm{mM}$ NIN, $10 \mathrm{mM}$ NED, $10 \mathrm{mM}$ NID, or $6 \mathrm{mM}$ AN was dissolved in $0.1 \mathrm{M} \mathrm{HCl} ; 10 \mathrm{mM} \mathrm{AD}$ was dissolved in $0.1 \mathrm{M} \mathrm{NaOH}$ and $15 \mathrm{mM} \mathrm{CN}$ or $10 \mathrm{mM} \mathrm{MN}$ was dissolved in water; $30 \mathrm{mM}$ atrazine, $30 \mathrm{mM}$ ametryne, $30 \mathrm{mM}$ prometryne, $30 \mathrm{mM}$ CEAT, or $30 \mathrm{mM}$ CIAT was dissolved in ethanol. These solutions were stable for months in screw-cap containers at room temperature. The growth medium used for carbon-limited growth was prepared similarly but contained a C:N ratio of about 1 . The term "buffered salts" refers to $10 \mathrm{mM}$ potassium phosphate buffer, $\mathrm{pH} 7.3$, containing $0.25 \mathrm{mM} \mathrm{MgSO}$.

Enrichment cultures were used to obtain isolates able to utilize a given $s$-triazine (Table I, excepting $M N$ ) as a sole and limiting source of nitrogen for growth. Inocula for enrichments were prepared from sewage or soil. Municipal sewage from a primary settling tank (Werdhölzli, Zürich) was centrifuged $\left(20000 \mathrm{~g}\right.$ for $10 \mathrm{~min}$ at $4^{\circ} \mathrm{C}$ ) and the supernatant fluid discarded to reduce the quantity of extraneous nitrogen source(s). The pellet was resuspended in buffered salts solution and washed twice more. The pellet was then suspended in buffered salts solution for use as inoculum. Samples $(5 \mathrm{~g})$ from each of four agricultural soils (from Ciba-Geigy Research Stations in Bex and Vufflens and from the Swiss Federal Research Station in Wädenswil) that had been exposed to one to seven treatments with $s$-triazine herbicides were mixed, suspended in $100 \mathrm{~mL}$ of a solution of buffered salts, shaken at $30^{\circ} \mathrm{C}$ for $1 \mathrm{~h}$, and allowed to settle for $30 \mathrm{~min}$. The supernatant fluid was passed through a Whatman No. 1 filter and the filtrate prepared for inoculation as described for sewage. Enrichment cultures $(3 \mathrm{~mL}$ in culture tubes closed with plastic caps) were nonsterile and contained 2.5 $\mathrm{mM}$ combined nitrogen, $5 \mathrm{mM}$ glucose, $5 \mathrm{mM}$ succinate, $10 \mathrm{mM}$ glycerol, and $0.4 \mathrm{~mL}$ of inoculum. The inoculated tubes were placed in a gas-tight container connected to a vacuum pump and gas cylinders. The container was evacuated to about $400 \mathrm{~Pa}$, filled with $\mathrm{He}$ to about $10^{5} \mathrm{~Pa}$, and again evacuated. The container was filled with a mixture containing $20 \%(\mathrm{v} / \mathrm{v}) \mathrm{O}_{2}$ and $80 \%(\mathrm{v} / \mathrm{v})$ He at a pressure of about $8 \times 10^{4} \mathrm{~Pa}$, closed, and incubated at 30 ${ }^{\circ} \mathrm{C}$. Under these conditions, the only nitrogen source known to be present was the $s$-triazine (or a control with ammonium ion). The first enrichment culture, including a control without nitrogen source, grew in 1-3 days. All enrichments were subcultured into homologous medium and incubated in the $\mathrm{N}_{2}$-free atmosphere. These cultures, which gave more growth (scored visually) than the control without a nitrogen source, were subcultured into homologous medium and incubated in the $\mathrm{N}_{2}$-free atmosphere. After three $s$-triazine-limited subcultures, positive enrichments were streaked on nutrient agar plates. A rep- resentative of each colony type was picked from the agar plates, and isolates that were able to utilize $s$-triazines were recognized by their growth in sterile selective liquid medium (homologous with enrichment) in the $\mathrm{N}_{2}$-free atmosphere. Positive isolates were streaked on nutrient agar plates and also proofed for dinitrogen fixation, assayed as growth in liquid culture without combined nitrogen in air. Isolates that did not fix nitrogen $(97 \%$ of the strains isolated) were picked from plates and grown in the appropriate selective liquid medium in air. This procedure of alternated growth in selective liquid medium and on nonselective agar plates was used both to minimize the risk of loss of degradative ability sometimes experienced on repeated streaking on nonselective media (Cook et al., 1978) and to reduce the chance of carrying a persistent contaminant through the isolation (Cowan and Liston, 1974). When the procedure yielded three successive homologous plates, an isolate was considered pure.

Stock cultures of each isolate were maintained in screw-cap tubes containing slants made with the appropriate s-triazine as the sole nitrogen source in the standard medium solidified with $2 \%(\mathrm{w} / \mathrm{v})$ Noble Agar (Difco Laboratories, Detroit, MI). Lower quality agar gave growth without an added nitrogen source, and a higher quality product (Purified Agar, Difco) prevented growth of strain A. No confirmed $s$-triazine utilizer grew on Noble Agar without a source of combined nitrogen.

Limited taxonomy was done, following the principles of Bergey's Manual, to ascertain that the strains were unlikely to be serious pathogens. Morphology was studied by phase-contrast microscopy, the Gram reaction was deduced from the cell surface observed by electron microscopy, and Roche Oxi-Ferm and Enterotubes were used in combination with the methods of Stanier et al. (1966).

Quantification of Growth and Substrate Utilization. Bacterial growth yields with limiting nitrogen sources were done at $30^{\circ} \mathrm{C}$ with $60-\mathrm{mL}$ cultures in $500-\mathrm{mL}$ fluted Erlenmeyer flasks mounted on an orbital shaker (2-3 revolutions/s). Media containing nitrogen sources at five concentrations between 0.0 and $2.5 \mathrm{mM}$ nitrogen were inoculated $(0.3 \% \mathrm{v} / \mathrm{v})$ with a culture induced to grow in a limiting amount of $s$-triazine. The carbon source was 10 $\mathrm{mM}$ lactate for the pseudomonads or $10 \mathrm{mM}$ glucose for the strains of Klebsiella. Before incubation, a sample of the culture was taken aseptically and centrifuged $(23000 \mathrm{~g}$ for $20 \mathrm{~min} \mathrm{a} 4^{\circ} \mathrm{C}$ ), and $2.7 \mathrm{~mL}$ of the supernatant fluid was added to $0.3 \mathrm{~mL}$ of $1 \mathrm{M} \mathrm{HCl}$ in a screw-cap vial. The sample was stored frozen. When the culture was outgrown (1-3 days), another sample of the culture supernatant fluid was taken, and growth was quantified as protein. The acidified samples of culture supernatant fluid were thawed, and a portion was neutralized with $1 \mathrm{M} \mathrm{NaOH}$ for analysis of ammonium ion and/or $s$-triazine. Similar experiments were done for carbon-limited growth.

Growth kinetics were followed in $250-\mathrm{mL}$ cultures in 1-L fluted Erlenmeyer flasks shaken at 2.5 revolutions/s at 30 ${ }^{\circ} \mathrm{C}$. The nitrogen source was about $2.5 \mathrm{mM}$ nitrogen, and the carbon source was $10 \mathrm{mM}$ lactate for the pseudomonads or $10 \mathrm{mM}$ glucose for Klebsiella strains. Inocula for growth experiments were prepared from exponentially growing cultures which were harvested aseptically $(10000 \mathrm{~g}$ for $20 \mathrm{~min}$ at $4^{\circ} \mathrm{C}$ ) after which the supernatant fluid was discarded and the pellet resuspended in a sterile solution of buffered salts and used immediately. Samples were taken at intervals to measure turbidity, protein, and the nitrogen source.

Cells for use in cell suspension studies were grown overnight in 1-L batches in 4-L fluted Erlenmeyer flasks 
Table II. Representative Strains Isolated and the $s$-Triazine Degraded

\begin{tabular}{|c|c|c|c|c|}
\hline \multicolumn{3}{|c|}{ strain isolated } & \multirow[b]{2}{*}{$\begin{array}{l}s \text {-triazine in } \\
\text { enrichment }\end{array}$} & \multirow[b]{2}{*}{$\begin{array}{c}\text { other }^{a} s \text {-triazines } \\
\text { utilized }\end{array}$} \\
\hline $\begin{array}{l}\text { desig- } \\
\text { nation }\end{array}$ & identity & source & & \\
\hline $\begin{array}{l}\mathrm{A} \\
\mathrm{D} \\
\mathrm{F} \\
90 \\
99\end{array}$ & $\begin{array}{l}\text { Pseudomonas sp. } \\
\text { Pseudomonas sp. } \\
\text { Pseudomonas sp. } \\
\text { K. pneumoniae } \\
\text { K. pneumoniae }\end{array}$ & $\begin{array}{l}\text { sewage } \\
\text { soil } \\
\text { soil } \\
\text { sewage } \\
\text { sewage }\end{array}$ & $\begin{array}{l}\text { AN } \\
\text { NID } \\
\text { NID } \\
\text { AD } \\
\text { CN }\end{array}$ & $\begin{array}{l}\text { NEN, NIN, MN, AD, CN } \\
\text { NED, AN, AD, CN } \\
\text { NED, AN, AD, CN } \\
\text { CN } \\
\text { AD }\end{array}$ \\
\hline
\end{tabular}

a The other eight $s$-triazines shown in Table I were not utilized reproducibly as nitrogen sources for growth in the enrichment cultures.

shaken at 2 oscillations $/ \mathrm{s}$ at $30^{\circ} \mathrm{C}$. The cells were harvested $\left(10000 \mathrm{~g}\right.$ for $20 \mathrm{~min}$ at $\left.4{ }^{\circ} \mathrm{C}\right)$ and washed twice in a solution of buffered salts, and the pellet was stored frozen. The pellet was thawed, suspended in a solution of buffered salts and washed, and the supernatant fluid was discarded. The pellet was resuspended in a solution of buffered salts, and experiments were done at a final concentration of about $0.3 \mathrm{mg}$ of protein $/ \mathrm{mL}$. Experiments $(30 \mathrm{~mL})$ to follow the conversion of $s$-triazines to ammonium ion were done in $100-\mathrm{mL}$ Erlenmeyer flasks shaken (reciprocal shaker; 2 oscillations/s) at $30{ }^{\circ} \mathrm{C}$. Samples were taken at intervals and centrifuged $(23000 \mathrm{~g}$ for 20 min at $4^{\circ} \mathrm{C}$ ), and the supernatant fluid was acidified and stored frozen. The latter experiment was modified to enable identification of NID (or NED) formed from NIN (or NEN) by strain A. The reaction volume was increased to $100 \mathrm{~mL}$ (in $500-\mathrm{mL}$ flasks) and the substrate concentration was $1 \mathrm{mM}$. When the reaction was complete $(7 \mathrm{~h})$, the cells were removed by centrifugation and the supernatant fluid was concentrated 10 -fold in a rotary evaporator. NID (or NED) did not crystallize from this liquid (solubility limit in water $\sim 0.5 \mathrm{mM}$ ), so it was pumped on to a $31 \times 2.5 \mathrm{~cm}$ LiChroprep RP-8 (40-63 $\mu \mathrm{m}$ diameter particles) column (Lobar; Merck, Darmstadt, FRG) and eluted with $5 \%(\mathrm{v} / \mathrm{v})$ methanol in water. The peak presumed to be NID (or NED) was collected, and the material was evaporated to dryness under a stream of $\mathrm{N}_{2}$. Portions of the material were analyzed by analytical HPLC, UV spectroscopy, and mass spectrometry.

\section{RESULTS}

Enrichment and Isolation of Organisms Utilizing $s$-Triazines. Enrichments (82) were done with $15 s$-triazines. Eight pure cultures of bacteria were obtained, each of which could grow on several of eight $s$-triazines. No fungi were isolated. Municipal sewage gave the enrichments for utilizers of $A N, A D$, and CN (six of eight isolates), but only soil exposed to multiple treatments of $s$-triazine herbicides gave enrichments able to utilize NED and NID (two of eight isolates). Five representative bacterial strains are shown in Table II; the other three strains were taxonomically identical with strain 90 and were not examined further. Organisms A, D, and F were identified as strains of Pseudomonas because they were strictly aerobic, oxidase-positive, motile rods which grew without growth factors in the $\mathrm{pH}$ range 6-8 and used both glucose and acetate as carbon sources; electron micrographs showed polar multitrichous flagella and a wavy surface characteristic of Gram-negative cell surfaces. The organisms could not be readily assigned to the well-characterized species of Pseudomonas by using the preliminary characteristics given by Stanier et al. (1966). Organisms 90 and 99 were identified as strains of Klebsiella pneumoniae because they were Gram-negative, facultatively anaerobic, oxidase-negative, nonmotile rods which grew anaerobically on glucose with gas production and grew aerobically with lactose and citrate as carbon sources; lysine decarboxylase and urease reactions were positive whereas ornithine decarboxylase and phenylalanine deaminase reactions were negative and there was no production of $\mathrm{H}_{2} \mathrm{~S}$ or indole.

$s$-Triazines were supplied singly as the sole and limiting sources of nitrogen in enrichment cultures. For the soluble $s$-triazines, unsuccessful enrichments were not turbid, so the low level of contamination from ammonium ion $(0.12$ mole fraction in NIN to 0.0 mole fraction in NID) caused no false positives. The elimination of dinitrogen from enrichments was essential to repress the growth of organisms fixing dinitrogen: the problem was extreme with enrichments containing $s$-triazines dissolved in ethanol, which turned out to be an excellent growth substrate for dinitrogen-fixing strains that did not grow on the other three carbon sources in the enrichment medium.

If the enrichment was initially turbid because the $s$ triazine was insoluble (atrazine, hydroxysimazine, hydroxyatrazine, or hydroxyprometryne), the turbidity test for a successful enrichment was inapplicable. In many of these initially turbid enrichments, larger clumps developed on incubation, and pure cultures could be obtained that were not dinitrogen fixers in liquid culture. However, on media solidified with Noble Agar slime-producing colonies of the same size developed, whether the $s$-triazine was supplied as the sole nitrogen source or whether the medium was $s$-triazine free. Slime produced in the enrichments presumably caused flocculation of the $s$-triazine.

Quantification of $s$-Triazine Utilization for Growth. Preliminary evidence for the utilization of the $s$-triazines as sole nitrogen sources was the growth yield of organisms (measured as protein) per mole of supplied nitrogen (Table III). In all cases (except NEN and NIN, see below) the yield of cells per mole of $s$-triazine nitrogen was similar to the yield of the same strain per mole of ammonium ion (e.g., $50-61 \mathrm{~g}$ of protein for strain $\mathrm{A}$ ). This strongly implied that the $s$-triazine nitrogen was quantitatively used by the bacteria for growth. In all cases (except NEN and NIN) all measured nitrogen-containing substrates were quantitatively removed from the growth medium (Table III). The growth yields were the gradients of lines obtained by plotting cell yield vs. initial concentration of the nitrogen source (the coefficient of correlation was always better than 0.99 ), and the cultures without combined nitrogen showed negligible growth; thus nitrogen fixation could not explain the results. Additional controls were the following: $s$-triazines were stable in sterile control experiments, no ammonium ion was taken up from the atmosphere, and cultures free of combined nitrogen but containing the acid plus alkali used to dissolve $s$-triazines and neutralize the solvent showed no significant growth. Strains $\mathrm{A}$ and $\mathrm{D}$ each grew with limiting lactate as the sole carbon source (and excess ammonium ion) with a yield of $6 \mathrm{~g}$ of protein $/ \mathrm{mol}$ of C.

Bacterial growth, where studied kinetically, was exponential (rates given in Table III). In the cases examined 
Table III. Bacterial Growth Yields, Specific Growth Rates, and Specific Degradation Rates When Utilizing Different Nitrogen Sources

\begin{tabular}{|c|c|c|c|c|c|}
\hline organism & $\begin{array}{l}\text { nitrogen }^{a} \\
\text { source }\end{array}$ & $\begin{array}{l}\text { nitrogen } \\
\text { source left } \\
\text { after growth }\end{array}$ & $\begin{array}{c}\text { growth } \\
\text { yield } \\
\text { (protein), } \\
\mathrm{g} / \mathrm{mol} \text { of } \mathrm{N}\end{array}$ & $\begin{array}{l}\text { specific }^{b} \\
\text { growth } \\
\text { rate, } h^{-1}\end{array}$ & $\begin{array}{c}\text { specificc } \\
\text { degradation } \\
\text { rate, mkat } / \mathrm{kg} \\
\text { of protein }\end{array}$ \\
\hline \multirow[t]{6}{*}{ Pseudomonas strain D } & $\mathrm{NH}_{4}^{+}$ & $\mathrm{nd}^{d}$ & 43 & 0.29 & 1.9 \\
\hline & NID & nd & 44 & 0.28 & 0.44 \\
\hline & NED & nd & 38 & & \\
\hline & AN & nd & 40 & 0.29 & 0.40 \\
\hline & $\mathrm{AD}$ & nd & 47 & 0.29 & 0.43 \\
\hline & $\mathrm{CN}$ & nd & 43 & 0.31 & 0.67 \\
\hline \multirow[t]{2}{*}{ Pseudomonas strain $\mathrm{F}$} & $\mathrm{NH}_{4}^{+}$ & nd & 46 & & \\
\hline & NID & nd & 46 & & \\
\hline \multirow[t]{7}{*}{ Pseudomonas strain A } & $\mathrm{NH}^{+}$ & nd & 54 & 0.52 & 2.6 \\
\hline & NIN $^{e}$ & NID & $13^{e}$ & 0.12 & 0.51 \\
\hline & $\mathrm{NEN}^{e}$ & NED & $13^{e}$ & 0.14 & 0.65 \\
\hline & MN & nd & 61 & 0.31 & 0.24 \\
\hline & AN & nd & 53 & 0.42 & 0.44 \\
\hline & $\mathrm{AD}$ & nd & 50 & 0.42 & 0.58 \\
\hline & $\mathrm{CN}$ & nd & 56 & 0.28 & 0.46 \\
\hline \multirow[t]{3}{*}{ K. pneumoniae strain 90} & $\mathrm{NH}_{4}^{+}$ & nd & 67 & 0.76 & 3.1 \\
\hline & $\mathrm{AD}^{4}$ & nd & 68 & 0.47 & 0.48 \\
\hline & $\mathrm{CN}$ & nd & 60 & $0.60^{f}$ & 0.93 \\
\hline \multirow[t]{3}{*}{ K. pneumoniae strain 99} & $\mathrm{NH}_{4}{ }^{+}$ & nd & 66 & 0.77 & 3.2 \\
\hline & $A D$ & nd & 63 & 0.31 & 0.34 \\
\hline & $\mathrm{CN}$ & nd & 63 & $0.63^{f}$ & 0.93 \\
\hline
\end{tabular}

${ }^{a}$ Initial concentration in growth medium $\sim 2.5 \mathrm{mM}$ nitrogen. ${ }^{b} \mu$, as defined by, e.g., Stanier et al. (1976). ${ }^{c}$ Refers to the respective nitrogen-containing substrate. ${ }^{d}$ Not detectable. $e$ Contaminated with $\mathrm{NH}_{4}^{+}$to a mole fraction of about 0.1 , so some $6 \mathrm{~g}$ of protein $/ \mathrm{mol}$ of $s$-triazine was due to the presence of $\mathrm{NH}_{4}{ }^{+}$. $f$ Rate for the first phase of growth.

Table IV. Products from the Degradation of $s$-Triazines by Nongrowing Suspensions of Bacteria

\begin{tabular}{|c|c|c|c|c|c|c|c|c|}
\hline \multirow[b]{3}{*}{ organism } & \multirow[b]{3}{*}{ substrate } & \multirow{3}{*}{$\begin{array}{c}\text { initial } \\
\text { substrate } \\
\text { concn, } \mathrm{mM}\end{array}$} & \multicolumn{6}{|c|}{ products } \\
\hline & & & \multicolumn{3}{|c|}{$\mathrm{NH}_{4}^{+}, \mathrm{mM}$} & \multirow{2}{*}{$\begin{array}{l}{ }^{14} \mathrm{CO}_{2}, \% \text { of } \\
\text { counts supplied } \\
\text { in substrate }\end{array}$} & \multirow{2}{*}{$\begin{array}{l}\text { residual }{ }^{14} \mathrm{C} \text { in } \\
\text { acidified reaction } \\
\text { mixture, } \%\end{array}$} & \multirow[b]{2}{*}{$\begin{array}{l}s \text {-triazine remaining } \\
\text { after reaction, } \mathrm{mM}\end{array}$} \\
\hline & & & $\begin{array}{l}\text { color } \\
\text { reaction }\end{array}$ & $\begin{array}{l}\text { enzyme } \\
\text { reaction }\end{array}$ & electrode & & & \\
\hline$\overline{\mathrm{D}^{a}}$ & NID & 0.41 & 1.5 & 1.4 & 1.7 & 85 & 1 & $n d^{b}$ \\
\hline $\mathrm{D}^{a}$ & NED & 0.37 & 1.6 & 1.4 & 1.8 & & & nd \\
\hline $\mathrm{D}^{c}$ & AN & 0.50 & 2.2 & 2.6 & 2.8 & 82 & 1 & nd \\
\hline $\mathrm{D}^{a}$ & $\mathrm{CN}$ & 0.7 & 2.1 & & & 85 & 0 & nd \\
\hline $\mathrm{A}^{c}$ & NIN & 0.50 & 0.51 & 0.48 & 0.41 & & & $0.53 \mathrm{mM}$ NID \\
\hline $\mathrm{A}^{c}$ & NEN & 0.48 & 0.41 & 0.43 & 0.34 & & & $0.48 \mathrm{mM}$ NED \\
\hline $\mathrm{A}^{c}$ & $\mathrm{MN}$ & 0.40 & 2.4 & & & & & nd \\
\hline $\mathrm{A}^{c}$ & AN & 0.40 & 1.9 & 2.0 & 2.2 & 73 & 6 & nd \\
\hline $\mathrm{A}^{d}$ & $\mathrm{CN}$ & 0.75 & 1.1 & & & 56 & 36 & nd \\
\hline $90^{e}$ & $\mathrm{AD}$ & 0.48 & 2.0 & & & & & nd \\
\hline $90^{e}$ & $\mathrm{CN}$ & 0.70 & 0.64 & & & 34 & 59 & nd \\
\hline$A^{c}+D^{a}$ & NIN & 0.50 & 2.5 & & & 84 & 1 & nd \\
\hline $\mathrm{A}^{c}+\mathrm{D}^{a}$ & NEN & 0.49 & 2.0 & 2.0 & 2.8 & 83 & 3 & nd \\
\hline none & $\mathrm{H}^{14} \mathrm{CO}_{3}^{-}$ & 3.0 & & & & 87 & 0 & \\
\hline
\end{tabular}

${ }^{a}$ Strain had been grown with NID as the nitrogen source. ${ }^{b}$ Not detectable. ${ }^{c}$ Strain had been grown with AN as the nitrogen source. $d$ Strain had been grown with $\mathrm{CN}$ as the nitrogen source. $e$ Strain had been grown with AD as the nitrogen source.

(strains D, A, 90, and 99), the growth rate with ammonium ion was only slightly faster than with a $s$-triazine as the sole and limiting nitrogen source (Table III), demonstrating that the $s$-triazines were good growth substrates. A typical growth curve is shown in Figure 2. Strain D grew exponentially with NID as the sole nitrogen source. The differential plot of substrate concentration vs. protein concentration (Figure 2, insert) was a straight line, demonstrating that substrate utilization was concomitant with growth. Similar data were obtained for strain A growing with ammonium ion, $\mathrm{AN}$, or $\mathrm{CN}$ as the sole and limiting nitrogen source (not shown). Strain 90 , in medium with limiting $\mathrm{AD}$, grew exponentially to a cell density corresponding to that of complete utilization of the nitrogen source, but strains 90 and 99 each showed biphasic growth with $\mathrm{CN}$ as a sole nitrogen source, and $\mathrm{CN}$ was exhausted before the start of the second phase in which about $30 \%$ of the protein was synthesized. Strain F grew in clumps and was not examined further.

The fact that $s$-triazine utilization was concomitant with growth (or faster in the cases of strains 90 and 99 utilizing $\mathrm{CN}$ ) allowed the specific degradation rate (millikatal per kilogram of protein) to be calculated from the specific growth rate (hour ${ }^{-1}$ ) and the growth yield (grams of protein per mole of $\mathrm{N}$ ). The data in the right-hand column of Table III were corrected for moles of nitrogen per mole of $s$-triazine.

Products from Bacterial s-Triazine Degradation in Nongrowing Suspensions. Suspensions of four strains (A, D, 90, and 99) were able to degrade $s$-triazines under nongrowing conditions, but as strains 90 and 99 were similar, data for strain 90 only are given. With exceptions (see below), the sole product from the nitrogen atoms in the $s$-triazines was ammonium ion, which was quantitatively recovered and identified (in representative experiments) by three independent methods (Table IV). The 


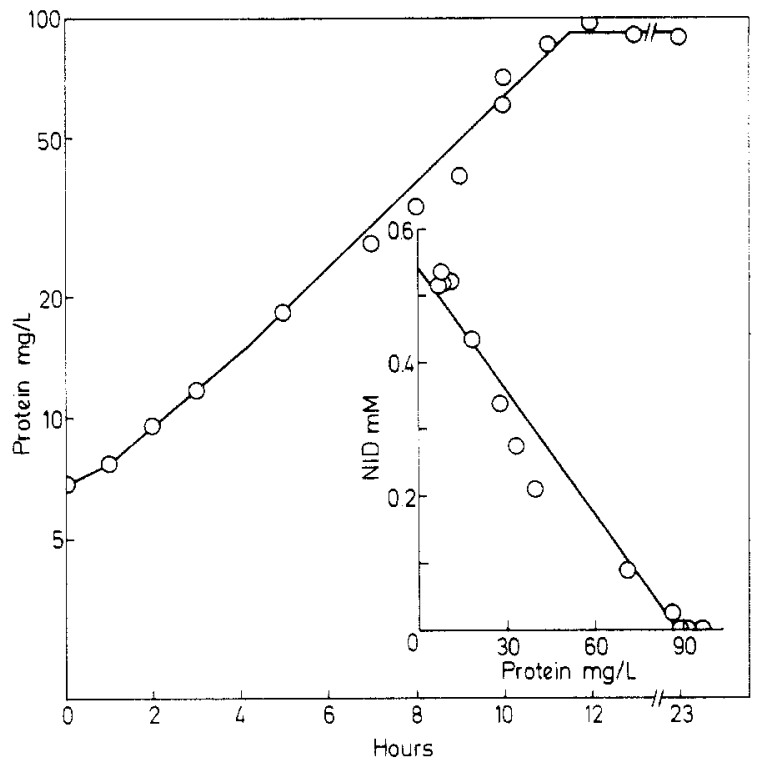

Figure 2. Growth of Pseudomonas strain D with NID as the sole and limiting nitrogen source. The insert is a differential plot of substrate concentration vs. the corresponding protein concentration.

$s$-triazines did not degrade spontaneously, and no increase of ammonium ion concentration was observed in the absence of bacteria. No ammonium ion was released from the cells in the absence of substrate. Quantification of ammonium ion in experiments with strain $\mathrm{A}$ was complicated in some batches by a lowered recovery of ammonium ion added to the suspension. We assume that the cells could store and subsequently remobilize the lipid-like poly ( $\beta$-hydroxybutyrate) and thus grow to a certain extent under these conditions.

The principal product from the carbon atoms in the $s$-triazine ring was carbon dioxide, tentatively identified by radiorespirometry (Table IV). No significant ${ }^{14} \mathrm{CO}_{2}$ was released in control experiments without cells, and no spurious counts were observed in controls without radioactivity. The yield of ${ }^{14} \mathrm{CO}_{2}$ from $s$-triazines (except from $\mathrm{CN}$ in strains $\mathrm{A}$ and 90 ) was close to the yield of ${ }^{14} \mathrm{CO}_{2}$ from $\mathrm{H}^{14} \mathrm{CO}_{3}{ }^{-}$in control experiments, and negligible radioactivity remained in solution after acidification (Table IV). Each $s$-triazine tested under these conditions could thus be completely degraded by the appropriate choice of organisms.

There was evidence for transient intermediates in the experiments summarized in Table IV. CN was tentatively identified by cochromatography (HPLC) as a transient intermediate in the degradation of NED by suspensions of strain D. Other intermediates were presumably formed during these experiments, because the appearance of ammonium ion was sometimes slower than the disappearance of the $s$-triazines we could assay. The extreme case was strain 90 degrading $\mathrm{CN}$, where $\mathrm{CN}$ was quantitatively removed from the reaction mixture, but the yields of ammonium ion and carbon dioxide were low (Table IV). We do not yet understand why this strain degraded $A D$ but not CN quantitatively to ammonium ion (Table IV) whereas both substrates were fully converted to cell material by growing cultures (Table III). A similar phenomenon was observed with strain $A$, which completely utilized the nitrogen from $\mathrm{CN}$ during growth (Table III) and completely eliminated CN from cell suspensions (Table IV) at about $1.8 \mathrm{mkat} / \mathrm{kg}$ of protein but yielded only about $50 \%$ of the $s$-triazine nitrogen and carbon as ammonium ion and carbon dioxide, respectively (Table IV).
Table V. UV Spectra of Products from NIN and NEN and of Authentic Materials

\begin{tabular}{lcl}
\hline & \multicolumn{2}{c}{ wavelength, $\mathrm{nm}$} \\
\cline { 2 - 3 } \multicolumn{1}{c}{ substance } & max & min \\
\hline NIN & 205 & $a$ \\
NEN & 205 & $a$ \\
NID & 226 & 209 \\
NED & 225 & 210 \\
product from NIN ${ }^{b}$ & 226 & 209 \\
product from NEN $^{b}$ & 225 & 210
\end{tabular}

${ }^{a}$ None measurable. $b$ The absorption coefficient of this material indicated only $70 \%$ purity, suggesting that the desalting step was only $95 \%$ effective.

Table VI. Mass Spectral Identification of NID and NED Produced from NIN and NEN by Strain A

\begin{tabular}{ccccc}
\hline & \multicolumn{4}{c}{ relative intensity } \\
\cline { 2 - 5 }$m / z^{a}$ & $\begin{array}{c}\text { authentic } \\
\text { NID }\end{array}$ & $\begin{array}{c}\text { product }^{b} \\
\text { from } \\
\text { NIN }\end{array}$ & $\begin{array}{c}\text { authentic } \\
\text { NED }\end{array}$ & $\begin{array}{c}\text { product } \\
\text { from } \\
\text { NEN }\end{array}$ \\
\hline 171 & 17 & 9 & 0 & 0 \\
170 & $79(M)$ & 88 & 0 & 0 \\
157 & 0 & 0 & 13 & 9 \\
156 & 7 & 8 & $100(\mathrm{M})$ & 100 \\
155 & 100 & 100 & 12 & 13 \\
142 & 11 & 12 & 4 & 6 \\
141 & 4 & 4 & 53 & 67 \\
129 & 56 & 64 & 12 & 6 \\
128 & 44 & 46 & 82 & 76 \\
113 & 4 & 5 & 4 & 6 \\
112 & 21 & 24 & 7 & 9 \\
98 & 3 & 4 & 6 & 7 \\
95 & 2 & 2 & 1 & 1 \\
91 & 0 & 0 & 2 & 2 \\
87 & 11 & 11 & 4 & 6 \\
85 & 17 & 21 & 22 & 28 \\
84 & 9 & 14 & 6 & 7 \\
70 & 14 & 15 & 13 & 20 \\
69 & 72 & 72 & 44 & 50 \\
58 & 52 & 70 & 1 & 0 \\
57 & 8 & 7 & 1 & 4 \\
56 & 4 & 4 & 22 & 35 \\
44 & 64 & 66 & 63 & 72 \\
43 & 43 & 54 & 40 & 63
\end{tabular}

${ }^{a}$ In the mass spectra, at least the two most intense ions are presented for every 14 mass units above $m / z 34$ (relative intensity >1). $b$ The fine detail of the spectrum of the product is not significantly different from that of the authentic material.

Strain A was able to utilize NEN (and NIN) with the apparently poor growth yield of about $12 \mathrm{~g}$ of protein $/ \mathrm{mol}$ of $\mathrm{N}$ (Table III). As indicated in Table III and quantified in Table IV, strain A converted NEN (or NIN) quantitatively to NED (or NID) and ammonium ion; the growth yield was thus in the normal range. NED (or NID) was not present in the substrate or in the stock cell suspension and was tentatively identified by cochromatography with authentic NED (or NID) by HPLC. The identification of the NED (or NID) was supported by UV spectra (Table V) and was confirmed by mass spectrometry (Table VI). NEN (or NIN) could be quantitatively converted to ammonium ion and carbon dioxide by mixtures of strains $\mathrm{A}$ and D (Table IV). The fate of the alkyl side chain has not yet been examined.

\section{DISCUSSION}

The isolation of bacteria on xenobiotics as nitrogen sources is rare [e.g., Hughes and Stafford (1976)]. There is a preliminary report of amitrole as a sole nitrogen source for bacteria (Campacci et al., 1977). Our approach to the 


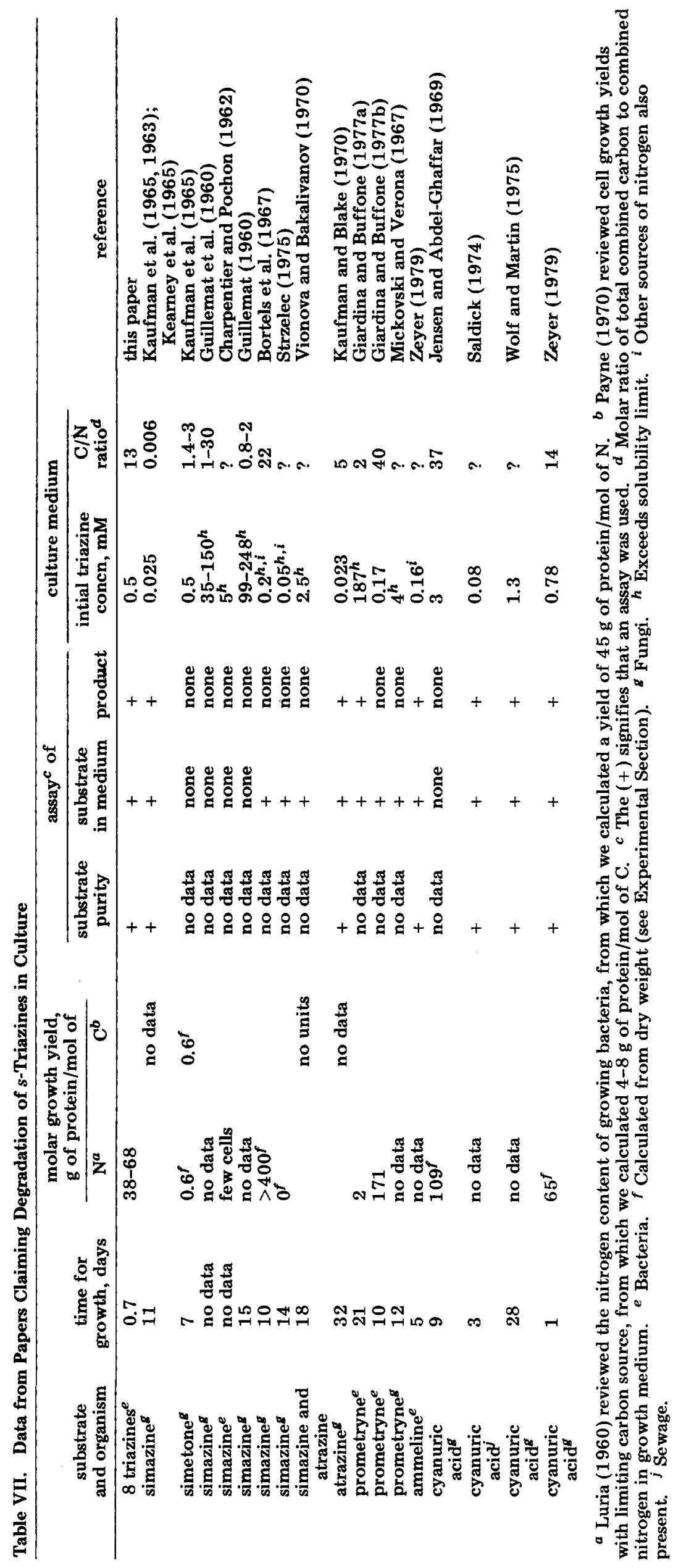


problem has been governed by the fact that $s$-triazines are sparingly soluble in water (generally $0.5 \mathrm{mM}$ or less; Beilstein et al., 1981) but that, e.g., $0.5 \mathrm{mM}$ NID represents $2.0 \mathrm{mM}$ nitrogen which allows the synthesis of about 100 $\mu \mathrm{g}$ of protein $/ \mathrm{mL}$ (Table VII, first line and footnote $a$ ), thus facilitating the simple visual turbidity test for bacterial growth used in the enrichment. The experiment would not work with NID as a carbon source. The ring carbons are at the oxidation level of carbon dioxide and are released quantitatively as carbon dioxide [Table IV; cf. Zeyer (1979), Wolf and Martin (1975), and Saldick (1974)], and they are thus unavailable to heterotrophic organisms. This leaves the carbon in the side chain to support growth, but a yield of $9 \mu \mathrm{g}$ of protein $/ \mathrm{mL}$ (Payne, 1970; cf. Table VII) is insufficient for a decisive turbidity test. Increasing the substrate concentration would give a turbid enrichment medium, the difficulties with which are described under Results. Furthermore, utilization of the side chain as a carbon source does not necessitate that the ring will be cleaved (Kaufman and Blake, 1970; Kearney et al., 1965) and allows no enrichment for utilization of $\mathrm{AN}, \mathrm{AD}$, or $\mathrm{CN}$. The critical practical problem to solve in our enrichment cultures, each of which should contain one limiting and recalcitrant nitrogen source, was the presence in air of a second and readily used nitrogen source (dinitrogen), whose presence led to the isolation of organisms able to fix dinitrogen. This problem was solved simply by replacing the air with an oxygen-helium mixture.

The growth yields in our experiments (Table III, summarized in Table VII) are consistent with the quantitative utilization of $s$-triazine nitrogen as a nitrogen source for bacteria because the molar growth yields are similar to those in a review of bacterial cell composition (Luria, 1960; cf. Table VII, first line). The yield is independent of the nature of the nitrogen source, and the organisms do not fix dinitrogen. This indirect proof of quantitative $s$-triazine utilization was supported by substrate disappearance (Table III), which was usually concomitant with growth (e.g., Figure 2), and the proof was confirmed by identifying ammonium ion as a quantitative product of $s$-triazine degradation in nongrowing cell suspensions (Table IV) and obtaining ${ }^{14} \mathrm{CO}_{2}$ in high yield from ring- ${ }^{14} \mathrm{C}$-labeled $s$-triazines. The growth yields of strains A and D $(6 \mathrm{~g}$ of protein $/ \mathrm{mol}$ of $\mathrm{C}$ ) with a limiting carbon source also lie in the typical range of literature values (Payne, 1970; $\mathrm{cf}$. Table VII).

Our isolates routinely display specific degradation rates during growth of $0.44 \mathrm{mkat} / \mathrm{kg}$ of protein or higher (Table III). These are better than the highest rates reported for $\mathrm{CN}$ [cf. Zeyer (1979)], of about $0.1 \mathrm{mkat} / \mathrm{kg}$ of protein, and refer to a range of at least five $s$-triazines (CN, AD, AN, NID, and NED). The behavior of nongrowing suspensions did not always mirror the behavior of growing cells. Thus, strain $\mathrm{A}$, which utilized $\mathrm{CN}$ concomitantly with growth at a specific rate of $0.46 \mathrm{mkat} / \mathrm{kg}$ of protein (Table III), degraded CN much faster in nongrowing suspensions (1.8 mkat $/ \mathrm{kg}$ of protein) but with incomplete conversion to ammonium ion and carbon dioxide (Table IV). The high specific degradation rate in nongrowing cells as compared to that in growing cells may indicate that the organisms can regulate the activity of the $\mathrm{CN}$-degrading enzymes during growth. The low yields of ammonium ion and carbon dioxide in nongrowing suspensions might be due to leakage of intermediates from the cell. This phenomenon and the biphasic growth of strain 90 and 99 with CN are under study, where we anticipate that transient excretion of intermediates will also help elucidate the deg- radative pathways involved in $s$-triazine metabolism.

Most of the work in this paper describes $s$-triazine degradation by single strains (Tables III and IV). It is possible, however, to use mixtures of different organisms to degrade substances which each organism alone cannot degrade. Thus, strain A, which deaminates NEN (and NIN) to NED (and NID) but which cannot dealkylate any of these compounds, can be mixed with strain D (which cannot deaminate or dealkylate NEN or NIN but is able to degrade NED and NID) to effect complete degradation of NEN (and NIN) to ammonium ion and carbon dioxide (Table IV).

This is the first substantiated report of complete microbial degradation of $N$-alkyl-s-triazines. The organisms involved are aerobic and facultatively anaerobic bacteria. Fungal dealkylation of simazine and atrazine has been shown by Kaufman and Blake (1970), Kearney et al. (1965), and Kaufman et al. $(1965,1963)$, but the rates are low (Table VII) and the degradation is limited to one or two reactions. However, the claim of Kaufman et al. (1965) that simetone can serve as a carbon and nitrogen source for fungal growth is not supported by our calculations from their data (Table VII, molar growth yields and footnotes $a$ and $b$ ). The other papers claiming microbial degradation of $s$-triazine herbicides in culture present neither data nor controls to support the claim and often describe work with the herbicide in suspension, a condition which we found to give highly misleading results. Low growth yields at high substrate concentrations probably indicate growth on impurities [e.g., Charpentier and Pochon (1962)], whereas excessively high yields may indicate dinitrogen fixation [e.g., Bortels et al. (1967)]. The failure to degrade a 1,2,4-triazine ring has been reported (Blecher et al., 1979).

The major $s$-triazine (about half the total) in untreated waste water from atrazine manufacture is NID (Zeyer, 1979), and we are exploring the possibilities of applying our strains to eliminate $s$-triazines from production waste waters. There would seem more promise in this direct approach to waste disposal than in the phenomena called cometabolism (Hulbert and Krawiek, 1977), which are characterized by low rates and incomplete metabolism. Thus Daughton and Hsieh (1977a,b) use cells growing, or grown, with parathion as the sole carbon source to destroy the pesticide in culture or in soil, respectively, and Munnecke $(1979,1980)$ applies enzymes in free or immobilized form to various aspects of the destruction of parathion wastes.

\section{ACKNOWLEDGMENT}

We are grateful to Jenny Bodmer for her competent technical assistance. We thank J. Seibl for obtaining the mass spectra and H. R. Ebersold for doing the electron microscopy.

\section{LITERATURE CITED}

Alexander, M. In "Microbial Ecology: a Conceptual Approach"; Lynch, J. M.; Poole, N. J., Eds.; Blackwell: Oxford, 1979; Chapter 4.4.

Beilstein, P.; Cook, A. M.; Hütter, R. J. Agric. Food Chem. 1981, preceding paper in this issue.

Blecher, R.; Koch, U.; Ballhause, B.; Lingens, F. Z. Pflanzenkr. Pflanzenschutz 1979, 86, 93-102.

Bortels, H.; Fricke, E.; Schneider, R. Nachrichtenbl. Dtsch. Pflanzenschutzdienstes (Braunschweig) 1967, 19, 101-105.

Campacci, E. F.; New, P. B.; Tchan, Y. T. Nature (London) 1977, $266,164-165$.

Charpentier, M.; Pochon, J. Ann. Inst. Pasteur, Paris 1962, 102, 501-504.

Conrad, R.; Schlegel, H. G. Arch. Microbiol. 1977, 112, 39-48.

Cook, A. M.; Daughton, C. G.; Alexander, M. Appl. Environ. Microbiol. 1978, 36, 668-672. 
Cook, A. M.; Hütter, R. In "Microbial Degradation of Xenobiotics and Recalcitrant Compounds"; Leisinger, Th.; Cook, A. M.; Nüesch, J.; Hütter, R., Eds.; Academic Press: London, 1981; Chapter 14.

Cowan, S. T.; Liston, J. In "Bergey's Manual of Determinative Bacteriology", 8th ed.; Buchanan, R. E.; Gibbons, N. E., Eds.; Williams and Wilkins: Baltimore, 1974; pp 10-13.

Cripps, R. E.; Roberts, T. R. In "Pesticide Microbiology"; Hill, I. R.; Wright, S. J. L., Eds.; Academic Press: London, 1978; Chapter 11.

da Fonseca-Wollheim, F.; Bergmeyer, H. U.; Gutmann, I. In "Methoden der enzymatischen Analyse", 3rd ed.; Bergmeyer, H. U.; Gawehn, K., Eds.; Verlag Chemie: Weinheim, 1974; pp 1850-1853.

Daughton, C. G.; Hsieh, D. P. H. Appl. Environ. Microbiol. 1977a, 34, 175-184.

Daughton, C. G.; Hsieh, D. P. H. Bull. Environ. Contam. Toxicol. $1977 \mathrm{~b}, 18,48-56$.

Esser, H. O.; Dupuis, G.; Ebert, E.; Marco, G. J.; Vogel, C. In "Herbicides: Chemistry, Degradation and Mode of Action"; Kearney, P. C.; Kaufman, D. D., Eds.; Marcel Dekker: New York, 1975; Chapter 2.

Fishbein, L. "Chromatography of Environmental Hazards"; Elsevier: Amsterdam, 1975; Vol. III, Chapter 17.

Giardina, M. C.; Buffone, R. Ann. Microbiol. Enzimol. 1977a, 27, 127-130.

Giardina, M. C.; Buffone, R. Chemosphere 1977b, 9, 589-594.

Guillemat, J. C. R. Hebd. Seances Acad. Sci., Ser. D 1960, 250, 1343-1344.

Guillemat, J.; Charpentier, M.; Tardieux, P.; Pochon, J. Ann. Epiphyt. 1960, 11, 261-295.

Harris, C. I.; Kaufman, D. D.; Sheets, T. J.; Nash, R. G.; Kearney, P. C. Adv. Pest Control Res. 1968, 8, 1-55.

Hughes, D. E.; Stafford, D. A. CRC Crit. Rev. Environ. Contral 1976, 6, 233-257.

Hulbert, M. H.; Krawiek, S. J. Theor. Biol. 1977, 69, 287-291.

Jensen, H. J.; Abdel-Ghaffar, A. S. Arch. Microbiol. 1969, 67, 1-5.

Jordan, L. S.; Farmer, W. J.; Goodin, J. R.; Day, B. E. Residue Rev. 1970, 32, 267-286.

Kaufman, D. D.; Blake, J. Soil Biol. Biochem. 1970, 2, 73-80.

Kaufman, D. D.; Kearney, P. C. Residue Rev. 1970, 32, 235-265.
Kaufman, D. D.; Kearney, P. C.; Sheets, T. J. Science (Washington, D.C.) $1963,142,405-406$.

Kaufman, D. D.; Kearney, P. C.; Sheets, T. J. J. Agric. Food Chem. $1965,13,238-242$.

Kearney, P. C.; Kaufman, D. D.; Sheets, T. J. J. Agric. Food Chem. $1965,13,369-372$.

Kennedy, S. I. T.; Fewson, C. A. Biochem. J. 1968, 107, 497-506.

Knuesli, E.; Berrer, D.; Dupuis, G.; Esser, H. In "Degradation of

Herbicides"; Kearney, P. C.; Kaufman, D. D., Eds.; Marcel

Dekker: New York, 1969; Chapter 2.

Lehninger, A. L. "Biochemistry", 2nd ed.; Worth: New York, 1975; pp 19, 208.

Luria, S. E. In "The Bacteria"; Gunsalus, I. C.; Stanier, R. Y., Eds.; Academic Press: New York, 1960; Vol. I, Chapter 1.

Mickovski, M.; Verona, O. Agric. Ital. (Pisa) 1967, 67, 67-76.

Munnecke, D. M. Biotechnol. Bioeng. 1979, 21, 2247-2261.

Munnecke, D. M. J. Agric. Food Chem. 1980, 28, 105-111.

Payne, W. J. Annu. Rev. Microbiol. 1970, 24, 17-52.

Pfennig, N.; Lippert, K. D. Arch. Microbiol. 1966, 55, 245-256.

Ramsteiner, K. A.; Hörmann, W. D.; Eberle, D. Z. Pflanzenkr. Pflanzenschutz, Sonderh. 1972, 6, 43-52.

Saldick, J. Appl. Microbiol. 1974, 28, 1004-1008.

Stanier, R. Y.; Adelberg, E. A.; Ingraham, J. L. "The Microbial World", 4th ed.; Prentice-Hall: Englewood Cliffs, NJ, 1976; Chapter 9.

Stanier, R. Y.; Palleroni, N. J.; Doudoroff, M. J. Gen. Microbiol. 1966, 43, 159-271.

Strzelec, A. Acta Microbiol. Pol., Ser. B 1975, 7, 91-96.

Vionova, G.; Bakalivanov, D. Meded. Fac. Landbouwwet., Rijksuniv. Gent 1970, 35, 839-846.

Weatherburn, M. W. Anal. Chem. 1967, 39, 971-974.

Wise, L. E.; Walters, E. H. J. Agric. Res. (Washington, D.C.) 1917, $10,85-92$.

Wolf, D. C.; Martin, J. P. J. Environ. Qual. 1975, 4, 134-139.

Zeyer, J. Ph.D. Dissertation No. 6446, Eidgenössische Technische Hochschule, Zürich, Switzerland, 1979. 